\title{
Black coatings: a review
}

\author{
J. Takadoum \\ Institut FEMTO-ST, UMR 6174 (CNRS, UFC, ENSMM, UTBM) \\ ENSMM - 26 chemin de l'épitaphe, 25030 Besançon Cedex, France \\ Te: 00-33-3-81-40-28-57 \\ Fax: 00-33-3-81-40-28-52 \\ Mail: Jamal.Takadoum@ens2m.fr
}

\begin{abstract}
Black coatings are widely used in numerous applications e.g., decorative coatings, solar panels, optical instruments. The films are mostly prepared by liquid phase deposition or vapor phase deposition. In this paper we review the techniques of deposition and the properties of the most important black coatings. Optical properties are particularly presented and discussed.
\end{abstract}

Keywords: Black, coatings, solar, panels, decorative.

\section{1-Introduction}

A black object is made from a material that absorbs all incoming light (all the colors of the visible spectrum). In reality objects which look black reflect always some light and consequently the ideal black object does not exist. There is no material on Earth that absorbs $100 \%$ of light at all angles and over all wavelengths.

In the field of surface treatments, black coatings are widely used for decorative or solar absorbing functions. The films deposited should have high mechanical properties (resistance to wear), a good resistance to corrosion and, for solar absorbing application, an ultra high absorbance capacity.

Materials used as solar panel must be capable of absorbing, storing and transmitting energy from the sun to a transport medium (generally water or water-based fluid coolant) with minimum thermal losses. Consequently, for this application, one must maximize absorption ( $\alpha$ $>0.95)$ and minimize emittance $(\varepsilon<0.10)$ of the used material. In addition, as transmission is usually by conduction, a good thermal conductivity is necessary (1).

Black coatings used for both decorative and solar absorbing functions are mostly prepared by liquid phase deposition or vapor phase deposition. Black nickel and black chromium are the most important electrodeposited materials whereas the films elaborated by vapor phase deposition include mainly titanium alloys and carbon based materials.

The aim of this paper is to review both method of preparation and properties of the main black coatings. 


\section{2- Black coatings obtained by liquid phase deposition}

Black nickel (2, 3), black zinc (4), black chromium (5), black phosphate (6) and black molybdenum $(7,8)$ based alloys are the most known black coatings obtained by liquid phase deposition. Among all, nickel based alloys and chromium based alloys have been particularly studied and are widely used for their efficient conversion of solar radiation into thermal energy.

\section{2-1. Nickel and nickel based alloys}

The black nickel coatings may be prepared by electroless (9) or electroplating techniques onto various metal substrates (10-13). Chemical conversion of a zinc-coated substrate is another way to obtain black nickel coatings (14-16).

Black nickel coatings have been prepared by chemical conversion of zinc-coated aluminum in the experimental conditions shown in Table 1 (17). The authors have studied the influence of the surface morphology of the base metal on the optical properties of the final coatings. They reported that the black nickel film prepared on a zinc-coated electropolished aluminum showed absorbance value of the order of 0.90 to 0.94 and emittance ranging from 0.08 to 0.15 .

\begin{tabular}{|l|l|}
\hline \multicolumn{1}{|c|}{ Bath constituents and parameters } & \multicolumn{1}{c|}{ Quantity $(g / l)$} \\
\hline $\mathrm{NiSO}_{4}$ & 75 \\
\hline $\mathrm{Ni}\left(\mathrm{NH}_{4}\right)_{2} \mathrm{SO}_{4}$ & 45 \\
\hline $\mathrm{ZnSO}$ & \\
\hline $\mathrm{NaSCN}$ & 37.5 \\
\hline
\end{tabular}

Table 1: Bath composition for chemical conversion of a zinc-coated aluminum to obtain black nickel coating (17).

Electrodeposited black nickel may be prepared using sulfate, chloride or sulfate and chloride based baths (Table 2) (18-19). The black color is due to the formation of $\mathrm{ZnS}$ and NiS particle in the films (20). Unfortunately, the obtained coatings do not present enough resistance to high humidity at elevated temperatures. To overcome this inconvenience more stable black coatings have been electrodeposited in nickel and sodium chlorine aqueous solution (21-23). A solar absorptance and a thermal emittance of 0.96 and 0.10 respectively were reported by the authors and confirmed in another study (24). In this latter work the author used the bath composition and operating conditions shown in Table 2 to depose a nickel black coating on aluminum and copper substrates. Using quite similar experimental conditions than in (24), black nickel has been electrodeposited on stainless steel substrate (25) (Table 2). The solar absorptance and thermal emittance values obtained were 0.91 and 0.1 respectively. 


\begin{tabular}{|c|c|c|c|c|c|}
\hline $\begin{array}{l}\text { Bath constituents } \\
\text { and parameters }\end{array}$ & $\begin{array}{l}\text { Quantity } \\
\text { (g./l) }\end{array}$ & $\begin{array}{l}\text { Quantity } \\
(\mathrm{g} / \mathrm{l})\end{array}$ & $\begin{array}{l}\text { Quantity } \\
(\mathrm{g} / \mathrm{l})\end{array}$ & $\underset{(g / l)}{\text { Quantity }}$ & $\begin{array}{l}\text { Quantity } \\
\text { (M) }\end{array}$ \\
\hline $\mathrm{NiSO}_{4}, 6 \mathrm{H}_{2} \mathrm{O}$ & 100 & & & & 0.63 \\
\hline $\mathrm{NiCl}_{2}, 6 \mathrm{H}_{2} \mathrm{O}$ & & 75 & 75 & 75 & 0.09 \\
\hline $\mathrm{H}_{3} \mathrm{BO}_{3}$ & & & & & 0.3 \\
\hline $\mathrm{KNO}_{3}$ & & & & & 0.2 \\
\hline $\mathrm{NaCl}$ & & & 30 & 30 & \\
\hline$\left(\mathrm{NH}_{4}\right)_{2} \mathrm{SO}_{4}$ & 15 & & & & \\
\hline$\left(\mathrm{NH}_{4} \mathrm{Cl}\right)$ & & 30 & & & \\
\hline $\mathrm{ZnSO}_{4}$ & 22 & & & & \\
\hline $\mathrm{ZnCl}_{2}$ & & 30 & & & \\
\hline $\mathrm{NaSCN}$ & 15 & 15 & & & \\
\hline $\mathrm{pH}$ & $5.5-6$ & $3.5-5.5$ & & & 4.6 \\
\hline Temperature & $26-32{ }^{\circ} \mathrm{C}$ & $\begin{array}{l}\text { Room } \\
\text { temperature }\end{array}$ & $25-27^{\circ} \mathrm{C}$ & $19-25^{\circ} \mathrm{C}$ & $25^{\circ} \mathrm{C}$ \\
\hline $\begin{array}{l}\text { Current density } \\
\left(\text { A. } \mathrm{dm}^{-2} \text { ) }\right.\end{array}$ & 0.2 & 0.15 & $\begin{array}{l}0.14(90 \mathrm{~s})+ \\
0.26(60 \mathrm{~s})\end{array}$ & $\begin{array}{l}0.07(3-6 \mathrm{~min}) \\
+ \\
0.13(1-2 \mathrm{~min}) \\
\text { Or } \\
0.11(3 \mathrm{~min})+ \\
0.22(1 \mathrm{~min})\end{array}$ & 0.5 \\
\hline Reference & 18 & 18 & 25 & 24 & 19 \\
\hline
\end{tabular}

\section{Table 2: Compositions and experimental conditions for black nickel electrodeposition}

Mechanical properties and corrosion resistance of black nickel coatings are greatly enhanced when phosphorus is co-deposited with nickel. Electroless black Ni-P with a phosphorus content ranged between $1 \%$ and $15 \%$ by weight may be obtained by using the composition and operation parameters of plating listed in Table 3.The black treatment was conducted by etching electroless plating nickel in oxidizing acid solution as follows. The samples were 
immersed into $5.5 \mathrm{M}$ sulfuric acid and $4.1 \mathrm{M}$ sodium nitrate solution at $50^{\circ} \mathrm{C}$ after $10 \mathrm{~s}$. After rinsing and drying, they were introduced into etching solution again for $5 \mathrm{~s}$. (26).

Chemical composition and AFM morphology analysis of the pre-etched and post-etched electroless nickel at various phosphorus content showed that surface became smoother and the nodular structure of the pre-etched film evolved into small convex closure-like structure after black treatment. In addition, etching leads to increase phosphorus content in the film due to a preferential dissolution of nickel atoms. Visible reflectance measurements on the films showed that optimum phosphorus content range to prepare low reflectance black nickel from 3 to $7 \mathrm{wt} \%$. In this case, the average reflectance measured at $633 \mathrm{~nm}$ was $0.46 \pm 0.02$.

\begin{tabular}{|l|l|}
\hline \multicolumn{1}{|c|}{ Bath constituents and parameters } & \multicolumn{1}{c|}{ Quantity (mol/l) } \\
\hline Nickel sulfate & 0.10 \\
\hline Sodium hypophosphite & $\begin{array}{l}0.08,0.1,0.13,0.15,0.20,0.25,0.3,0.35, \\
0.40\end{array}$ \\
\hline Sodium acetate & 0.15 \\
\hline D,L-Malic acid & 0.03 \\
\hline Citrate acid & 0.02 \\
\hline Succinic acid & 0.05 \\
\hline Lauryl sodium sulfate & $8 \mathrm{mg} / \mathrm{l}$ \\
\hline & 5.8 \\
\hline pH & $85 \pm 2^{\circ} \mathrm{C}$ \\
\hline Temperature & \\
\hline
\end{tabular}

Table 3: Bath composition and operating conditions of electroless Ni-P deposition (26)

In another study, an electroless Ni-P film deposited onto aluminum substrate overlayered with a zinc film has been obtained using the plating conditions shown in Table 4 (14). Blackened of electroless nickel was carried out by immersion in an acid solution. Three solutions at different concentrations were used: (a) nitric acid, (b) sulphuric acid + nitric acid, (c) nitracid + sulfuric acid + potassium permanganate. Nitric acid $(9 \mathrm{M})$ was found to provide highest solar absorptance value of the order of 0.995 . Surface analysis have shown that the pre-etched film contains $93.15 \%$ nickel and $6.81 \%$ phosphorus by weight whereas the etched coating showed lower nickel and phosphorus content (nickel $90.06 \%$, phosphorus 5.75 and oxygen $4.19 \%$ by weight). The black nickel obtained after etching consists of oxides $\left(\mathrm{NiO}, \mathrm{Ni}_{2} \mathrm{O}_{3}\right)$ and some nickel phosphate. The black color is due to the chemical composition of the film and to its surface morphology which consists of a dense array of microscopic, conical pores perpendicular to the surface which act as light traps and is capable of absorbing $99.5 \%$ light in solar region. Since the thickness of electroless nickel decreases during etching a higher 
thickness of electroless coating is required. The optimum coating thickness of electroless nickel is about $30 \pm 2 \mu \mathrm{m}$ to achieve the ultra high solar absorbance after etching. The obtained electroless black coatings showed a good: (a) resistance to corrosion, (b) thermal stability (c) resistance to humidity. In addition the coatings have an excellent adhesion and a high Vickers hardness value of 575.

\begin{tabular}{|l|l|}
\hline \multicolumn{1}{|c|}{ Bath constituents and parameters } & \multicolumn{1}{c|}{ Quantity (g/l) } \\
\hline Nickel sulphate, $\mathrm{NiSO}_{4} \cdot 7 \mathrm{H}_{2} \mathrm{O}$ & 30 \\
\hline Sodium hypophosphite, $\mathrm{NaH}_{2} \mathrm{PO}_{2}$ & 10 \\
\hline Sodium citrate, $\mathrm{Na}_{3} \mathrm{C}_{6} \mathrm{H}_{5} \mathrm{O}_{7} \cdot 2 \mathrm{H}_{2} \mathrm{O}$ & 12.5 \\
\hline Sodium acetate, $\mathrm{CH}_{3} \mathrm{COONa}_{2}$ & 5.0 \\
\hline Thiourea, $\mathrm{NH}_{2} \mathrm{CSNH}_{2}$ & 0.001 \\
\hline \multicolumn{2}{|c|}{ Operating conditions } \\
\hline pH & 4.7 \\
\hline Temperature & $88-90{ }^{\circ} \mathrm{C}$ \\
\hline Filtration & Continuous \\
\hline Time & $3 \mathrm{~h}$ \\
\hline Coating Thickness & $30 \pm 2 \mu \mathrm{m}$ \\
\hline Water rinse & \\
\hline
\end{tabular}

Table 4: Solution used for Ni-P electroless deposition (14)

The influence of the substrate nature and its roughness on optical properties of black nickel coatings has been reported in numerous studies. In (27) the authors used a bath composed of nickel, nickel sulfate, nickel ammonium sulfate, zinc sulfate and sodium thiocyanate to electrodepose black nickel coatings on various substrates (aluminum, copper and stainless steel). Bead-blasted, polished and unfinished samples of the studied materials were used. The results showed that the maximum absorbance value depends on surface finish more heavily than the base metal. For bead blasted substrates, absorbance reaches 0.93 in some cases while it is lower for polished and unfinished samples.

Relation between plating time and optical properties of black nickel coatings has been studied in (16). It has been found that as the coating thickness increases from 1 to 10 microns, the solar absorbance changes from 0.96 to 0.90 whereas the emittance of the coating increases with thickness (from 0.11 to 0.87 ). A change of optical properties of black nickel coating with thickness has also been observed and discussed in (28-31). 
Black nickel-cobalt and black nickel-copper alloys may also be obtained in black color by electrodeposition.

Black Ni-Co coatings have been electrodeposited using the experimental conditions shown in Table 5 (28-29). An optimized film has been produced at a current density of $3.5 \mathrm{Adm}^{-2}$ for a duration of 30 seconds. The obtained film possesses a solar absorbance of 0.91 and a thermal emittance of 0.04 (28). This coating is constituted from particles of highly irregular shape, micro roughness and dentritic like structure. The high degree of solar absorption in this material has been attributed to optical interference and surface roughness which depends on the coating thickness. In addition it was pointed out that current density employed for deposition has a great influence on the optical properties of the coating since higher current densities require less deposition time to obtain a given coating thickness.

\begin{tabular}{|l|l|}
\hline Bath constituents and parameters & Quantity $(\mathbf{g} / \mathbf{l})$ \\
\hline Nickel sulfate & 10 \\
\hline Cobalt sulfate & 10 \\
\hline Ammonium acetate & 10 \\
\hline \multicolumn{2}{|c|}{ Operating conditions } \\
\hline $\mathrm{pH}$ & 6.2 \\
\hline Temperature $\left({ }^{\circ} \mathrm{C}\right)$ & $35^{\circ} \mathrm{C}$ \\
\hline Current density $\left(\mathrm{A} \cdot \mathrm{dm}^{-2}\right)$ & $3-10$ \\
\hline
\end{tabular}

\section{Table 5: Bath composition and operating conditions for black nickel-cobalt electrodeposition (28)}

Electrodeposited black Ni-Cu on thin molybdenum foils has been studied in (30-31). Black films have been obtained from the bath solution given in Table 6. Table 7 shows that the optical properties of the films $(\alpha, \varepsilon)$ are increasing function of deposition time (30). Similar result was obtained with Ni-Co electrodeposited films (28). In another study, coherent, inclusion and pore free electrodeposited $\mathrm{Ni}-\mathrm{Cu}$ black solar selective coatings with good optical properties $(\alpha=0.94$ and $\varepsilon=0.10)$ were obtained from triethanolamine complex bath solution containing ammonium persulfate (31). 


\begin{tabular}{|c|c|c|}
\hline $\begin{array}{l}\text { Bath constituents and } \\
\text { parameters }\end{array}$ & Quantity (g/l) & Quantity (g/l) \\
\hline $\mathrm{Cu}\left(\mathrm{NO}_{3}\right)_{2}$ & 2.5 & \\
\hline$\left(\mathrm{NH}_{4}\right)_{2} \mathrm{NiSO}_{4} \cdot 6 \mathrm{H}_{2} \mathrm{O}$ & 20.0 & \\
\hline EDTA & 2.5 & \\
\hline $\mathrm{H}_{3} \mathrm{BO}_{3}$ & 10.0 & 10.0 \\
\hline $\mathrm{CuSO}_{4} .5 \mathrm{H}_{2} \mathrm{O}$ & & 20.0 \\
\hline $\mathrm{NiSO}_{4} \cdot 6 \mathrm{H}_{2} \mathrm{O}$ & & 20.0 \\
\hline$(\mathrm{NH} 4)_{2} \mathrm{~S}_{2} \mathrm{O}_{8}$ & & 10.0 \\
\hline$\left(\mathrm{HOCH}_{2} \mathrm{CH}_{2}\right)_{3} \mathrm{~N}$ & & $20.0 \mathrm{ml} / 1$ \\
\hline \multicolumn{3}{|c|}{ Operating conditions } \\
\hline $\mathrm{pH}$ & 5.2 & 5 \\
\hline Temperature $\left({ }^{\circ} \mathrm{C}\right)$ & $27^{\circ} \mathrm{C}$ & $27^{\circ} \mathrm{C}$ \\
\hline Current density $\left(\mathrm{A} \cdot \mathrm{dm}^{-2}\right)$ & 0.5 & 0.5 \\
\hline Duration & $30 \mathrm{~s}$ & $30 \mathrm{~s}$ \\
\hline Substrate & Mo-sheet & Mo-sheet \\
\hline Reference & 30 & 31 \\
\hline
\end{tabular}

Table 6: Bath composition and operating conditions for black nickel-copper electrodeposition (30-31)

\begin{tabular}{|l|l|l|}
\hline Deposition time $(\mathbf{s})$ & Absorption $(\boldsymbol{\alpha})$ & Emittance $(\boldsymbol{\varepsilon})$ \\
\hline 15 & 0.90 & 0.08 \\
\hline 30 & 0.94 & 0.09 \\
\hline 45 & 0.95 & 0.12 \\
\hline 60 & 0.96 & 0.16 \\
\hline 90 & 0.96 & 0.19 \\
\hline
\end{tabular}

Table 7: Optical properties of the films obtained in the experimental conditions shown in Table 6 (30) 


\section{2- Chromium and chromium based alloys}

Black chromium may be obtained by electrodeposition from hexavalent chromium processes based on chromic acid $\left(\mathrm{CrO}_{3}\right)$ (32) as well as by chromate conversion (33). Black chromium is known to offer better corrosion resistance than nickel films especially when formic acid is added to the solution used for the electrodeposition. Indeed it has been shown that surface modification with an adsorbed layer of formic acid significantly lowered the susceptibility of coatings to local corrosion (32).

Black chromate conversion films have been deposited on $\mathrm{Zn}$ and Co-Zn plated steel substrate by immersion in the chromating baths presented in Table 8 (33). $\mathrm{Zn}$ and $\mathrm{Zn}-\mathrm{Co}$ sublayers have been deposited in acidic solution as shown in Table 9 (33). The plating has been conducted at room temperature and under a cathodic current density of $1.5 \mathrm{~A}_{\mathrm{dm}}{ }^{-2}$. The obtained film contains $0.25-1.0 \%$ cobalt by weight. A comparative study between the reflective spectra of black films formed in chromating solutions with different compositions (Table 8) has been conducted. The investigation showed that the presence of an organic additive, ethoxylated aliphatic alcohols $\mathrm{C}_{12}-\mathrm{C}_{14}$ with 18 ethoxy groups, as well as $\mathrm{Na}_{2} \mathrm{SiO}_{3}$ in the formulation affects adsorption properties of the coatings. In addition, the obtained results showed that black coating deposited on the zinc sublayer presented a coefficient of solar absorption of $\alpha=0.88-0.90$. When the zinc sublayer contains small amounts of cobalt (up to 1 wt \%), a coefficient of absorption of $\alpha=0.90-0.93$ was obtained. This high absorption coefficient is due to the inclusions of cobalt which penetrates from the metal sublayer into the chromate film. In addition, it has been shown that the presence of Co increases the corrosion resistance of the coating (33).

\begin{tabular}{|l|l|l|l|l|l|l|l|l|}
\hline Component (g/l) & \multicolumn{7}{|c|}{ Solution } \\
\hline & 1 & 2 & 3 & 4 & 5 & 6 & 7 & 8 \\
\hline $\mathrm{CrO}_{3}$ & 18 & 18 & 18 & 18 & 18 & 18 & 18 & 18 \\
\hline $\mathrm{SO}_{4}^{-2}$ & 9 & 9 & 9 & 9 & 9 & 9 & 9 & 9 \\
\hline $\mathrm{AgNO}_{3}$ & 0.4 & - & - & - & 0.4 & 0.4 & 0.4 & - \\
\hline $\mathrm{Na}_{2} \mathrm{SiO}_{3}$ & - & - & 5 & 5 & 5 & - & 5 & - \\
\hline Organic additive & - & 0.1 & - & 0.1 & - & 0.1 & 0.1 & - \\
\hline
\end{tabular}

Table 8: Bath compositions of chromating solutions (33) 


\begin{tabular}{|l|l|l|}
\hline Component (g/l) & $\begin{array}{l}\text { Electrolyte } \quad \boldsymbol{1} \\
\text { (Zn film) }\end{array}$ & $\begin{array}{l}\text { Electrolyte 2 } \\
\text { (Zn-Cofilm) }\end{array}$ \\
\hline Zinc chloride & 80 & 80 \\
\hline $\begin{array}{l}\text { Ammonium } \\
\text { chloride }\end{array}$ & 180 & 180 \\
\hline Boric acid & 20 & 20 \\
\hline Cobalt chloride & - & $20-80$ \\
\hline Basic additive & 50 & 50 \\
\hline Brightener & 10 & 6 \\
\hline
\end{tabular}

Table 9: Bath compositions of $\mathrm{Zn}$ and $\mathrm{Zn}$-Co

films electrodeposition (33)

Electrodeposition of black chromium is mainly achieved in the conditions shown in Table 10 (32, 34-36). Characterization of black chromium coatings studied in (34) has shown that the most external layers were formed mainly by $\mathrm{Cr}_{2} \mathrm{O}_{3}$ with a selectivity of 3.41 . After thermal treatment of the black chromium samples the composition of external layers changes with increasing amount of $\mathrm{Cr}_{2} \mathrm{O}_{3}$ and the selectivity increased to 3.91. Another study (37) has also pointed out that thermal annealing at $400^{\circ} \mathrm{C}$ leads to the conversion of the hydroxide present at the surface into $\mathrm{Cr}_{2} \mathrm{O}_{3}$. In addition no evidence for metallic chromium was found.

\begin{tabular}{|c|c|c|c|c|}
\hline Bath constituents & \multicolumn{4}{|c|}{ Concentration $(\mathrm{g} / \mathrm{l})$} \\
\hline $\mathrm{CrO}_{3}$ & 200 & 364 & 250 & $250-400$ \\
\hline $\mathrm{NaNO}_{3}$ & 2 & & & \\
\hline $\mathrm{Na}_{2} \mathrm{SiF}_{6}$ & 0.2 & & & \\
\hline $\mathrm{CH}_{3} \mathrm{COOH}$ & & & & $5-10$ \\
\hline $\mathrm{KNO}_{3}$ & & 2.3 & & \\
\hline $\mathrm{BaCO}_{3}$ & & 9.1 & & \\
\hline \multicolumn{5}{|l|}{$\mathrm{CH}_{3} \mathrm{COOH}$} \\
\hline $\mathrm{H}_{2} \mathrm{SiF}_{6}$ & & 1.8 & 0.5 & \\
\hline \multicolumn{5}{|c|}{ Operating conditions } \\
\hline Temperature $\left({ }^{\circ} \mathrm{C}\right)$ & 20 & & $20-25$ & 30 \\
\hline $\begin{array}{ll}\text { Current } & \text { density } \\
\left(\text { A. } \mathrm{dm}^{-2}\right) & \end{array}$ & & & $25-30$ & $80-100$ \\
\hline Reference & 32 & 34 & 35 & 36 \\
\hline
\end{tabular}

Table 10: Bath composition and operating conditions for black chromium electrodeposition 
However, although chromate is an excellent corrosion inhibitor, it has been recognized a highly toxic, sensitizing and carcinogenic. Since trivalent chromium is not toxic and closely resembles the characteristics of hexavalent chromium it represents the suitable alternative for hexavalent chromium replacement. Recently, a formulation mainly based on a trivalent chromium plating solution was proposed to electrodeposit black chromium (Table 11) (38).

\begin{tabular}{|l|l|}
\hline Bath constituents & Quantity $(\mathbf{g} / \mathbf{l})$ \\
\hline $\mathrm{CrCl}_{3} \cdot 6 \mathrm{H}_{2} \mathrm{O}$ & 266 \\
\hline $\mathrm{CoCl}_{2} \cdot 6 \mathrm{H}_{2} \mathrm{O}$ & 15 \\
\hline $\mathrm{H}_{2} \mathrm{SiF}_{6}$ & $8-12$ \\
\hline $\mathrm{NaH}_{2} \mathrm{PO}_{4}$ & 4 \\
\hline $\mathrm{NaF}$ & 21 \\
\hline Operating conditions & \\
\hline Temperature & $\begin{array}{l}\text { Room } \\
\left({ }^{\circ} \mathrm{C}\right)\end{array}$ \\
\hline Current density $\left(\mathrm{mA} \cdot \mathrm{cm}^{-2}\right)$ & $200-500$ \\
\hline Time (min) & 1 \\
\hline
\end{tabular}

Table 11: Bath compositions and operating conditions of black trivalent chromium electrodeposition (38)

In this study, the influence of hexafluorosilicic acid $\left(\mathrm{H}_{2} \mathrm{SiF}_{6}\right)$ was particularly analyzed. It has

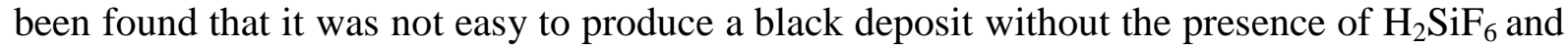
a minimum concentration $(8 \mathrm{~g} / \mathrm{l})$ has to be attained in order to favor the formation of black chromium. The obtained coating was a mixture of $\mathrm{Cr}, \mathrm{Cr}_{2} \mathrm{O}_{3}, \mathrm{CrO}_{3}$ and $\mathrm{Cr}(\mathrm{OH})_{3}$ with a solar absorbance of 0.97 . In addition, it has been reported that a cobalt addition to electroplating bath improves its efficiency and the optical properties of black chromium coating. The author reported also that the thermal treatment of the black chromium coating up to $400^{\circ} \mathrm{C}$ has a slight effect on the absoptance properties.

Black coatings using chromium trivalent ions instead of its hexavalent ions were also obtained with an optimized design of the bath (Table 12). The obtained black coating had an absorption coefficient of 0.96 . In this study, the authors have investigated the role of various additives and concluded that fluoride and dihydrogen phosphate anions are suitable additive materials (39). 


\begin{tabular}{|c|c|}
\hline Bath constituents & Quantity \\
\hline $\mathrm{Cr}^{+3}$ ion concentration & $1 \mathrm{M}$ \\
\hline $\mathrm{Co}^{+2}$ ion concentration & $15 \mathrm{~g} / 1$ \\
\hline Sodium hypophosphite concentration & $0.75 \mathrm{M}$ \\
\hline Sodium dihydrogen phosphate concentration & $4 \mathrm{~g} / 1$ \\
\hline Sodium fluoride concentration & $0.5 \mathrm{M}$ \\
\hline \multicolumn{2}{|c|}{ Working conditions } \\
\hline Electroplating temperature & $30^{\circ} \mathrm{C}$ \\
\hline Electroplating time & 1 minute \\
\hline Electroplating current density & $0.35 \mathrm{~A} / \mathrm{cm}^{2}$ \\
\hline $\mathrm{pH}$ of the electrolyte & Natural (0.5-1) \\
\hline
\end{tabular}

Table 12: Bath compositions and operating conditions of black trivalent chromium electrodeposition (39)

\section{3- Black coatings obtained by vapor phase deposition technique}

Black coatings elaborated by PVD or PECD techniques are widely used in decorative applications. Among them, carbon and titanium based compounds are the most important.

While the concept of absorption (or absorptance) introduced by the parameter $\alpha$ is the most widely used in the case of materials for solar applications, in the field of decoration one define the color by using the CIE system which is based on human perception of color. In this case, black color is estimated from the value of the parameter $\mathrm{L}^{*}$ which is a measure of lightness of an object and which indicates its reflecting properties. The parameters $\alpha$ and $\mathrm{L}^{*}$ measure the same property but there is no link between these standards.

Let us remind that the CIE system has been introduced by the International Lighting Committee (Comité International de l'Eclairage). With this system, color is expressed using three parameters or coordinates $\mathrm{L}^{*}, \mathrm{a}^{*}$ and $\mathrm{b}^{*}$.

The coordinate $\mathrm{L}^{*}$, which expresses luminosity, ranges from 0 for a black object to 100 for a white object and varies continuously between these extremes. $\mathrm{L}^{*}$ is represented as a vertical axis, whereas the horizontal plane comprises the two axes $a^{*}$ and $b^{*}$. The coordinate $a^{*}$ indicates position between red and green (positive values of a* indicate red while negative values of $a^{*}$ indicate green), whereas the coordinate $b^{*}$ indicates position between yellow and blue (positive values of $b^{*}$ indicate yellow while negative values of $b^{*}$ indicate blue)

\subsection{Black titanium based compounds}

TiCO coatings obtained using $\mathrm{CO}_{2}$ as a reactive gas show a black color but insufficient hardness and wear resistance (hardness $=400 \mathrm{HV}$ ). Mechanical properties of these coatings were improved by using TiAlCO (hardness $=13 \mathrm{GPa}$ ) and TiAlCON (hardness $=11$ to 17 $\mathrm{GPa}$ depending on nitrogen content) compounds. A hardness of $13 \mathrm{GPa}$ was obtained for an ideal black color TiAlCON film $\left(\mathrm{L}^{*}=40, \mathrm{a}, \mathrm{b}<1\right)$ (40). In another study TiCON coatings produced by PVD have permitted to obtain several tones of black for decorative applications (41). A titanium target was sputtered in an argon (working gas) + gas mixture (oxygen and nitrogen source) + acetylene (carbon source) atmosphere. The results reported in this study showed that with increasing the oxygen content in the film, the metallic dark grey color of 
titanium carbide became very dark or black with the increase of the oxygen content in the films. In addition when the partial pressure $\mathrm{PO}_{2}+\mathrm{N}_{2}$ exceeds $0.11 \mathrm{~Pa}$ the brightness situates between 45 and 50 and $\left\{a^{*}, b^{*}\right\}$ tends to be closer to $\{0,0\}$.

\subsection{Carbon and carbon based compounds}

Diamond-like Carbon (DLC) films are also used as black coatings. These films combine high values for hardness (2000 -10 $000 \mathrm{HV})$ with a low friction coefficient (0.1- 0.2) and great chemical stability (42-45).

DLC is made from a mixture of graphite (sp2 hybridization state) and diamond (sp3 hybridization state). Its properties can vary considerably as a function of the graphite/diamond ratio and the proportion of hydrogen it contains. Its mechanical properties can be rapidly degraded when the temperature exceeds $400^{\circ} \mathrm{C}$ (46). In this case, there is a sharp drop in the coating hardness due to the dehydrogenation of the material and the transformation of the carbon atoms from the $\mathrm{sp} 3$ to the $\mathrm{sp} 2$ form.

Recently, a nao-structured multilayer coating of a combination of a soft (a-C:H) produced by PECVD together with a hard layer $\left(\mathrm{Cr} / \mathrm{Cr} 3{ }_{-} \mathrm{C}_{\mathrm{x}}\right)$ produced by PVD allows to obtain colors between black and metallic $\mathrm{Cr}$ like depending on the thickness of the top $\mathrm{Cr}$ layer. It has been found that black color is obtained with $5 \mathrm{~nm}$ thick $\mathrm{Cr}$ layer whereas higher $\mathrm{Cr}$ film thickness (> $30 \mathrm{~nm}$ ) gives a metallic $\mathrm{Cr}$ like (47).

The world's blackest material that absorbs $99.95 \%$ of light with a total reflectance of $0.045 \%$ has been created two years ago from carbon nanotubes (average diameter of $8-10 \mathrm{~nm}$ ) produced by water-assisted chemical vapor deposition (CVD) process (48).

The surface of a carbon nanotube carpet was turned irregular and rough to minimize its optical reflectance. It has been shown that the obtained optical properties are the combination of the low density array, the nanometer-size nanotubes, and the random surface profile that makes the material an ideal black object.

The total reflective index of this material is about $0.045 \%$, which is three times lower than the nickel-phosphorus alloy considered till now as the blackest material in the world. Basic black paint, by comparison, has a reflective index of 5\% to $10 \%$ (49-50). "This material is almost 30 times darker than a carbon substance used by the US National Institute of Standard and Technology as the current benchmark of blackness" (51).

\subsection{Comparison between carbon and titanium based compounds}

To choose the most resistance black coating to abrasion for an application in watch industry, a comparative study resistance to abrasion has been conducted between TiAlCON, DLC and DLC coated CrN or TiAlN films deposited on an austenitic stainless steels 316L which is the most common steel used for coverings in the watch industry (40).

Figure 1 presents the results of the coatings resistance to abrasion after a period of $48 \mathrm{~h}$ of testing using an abrasive wear test by vibration according to standard ISO 3160-3. The coatings were classified on a scale of 0 to 10,10 being the value attributed to the sample not 
used. The TiAlCON layers were compared to two DLC market coatings (DLC1 and DLC2). The effect of a hard underlayer (CrN (hardness $=1800-2000 \mathrm{HV}$ ) or TiAlN (hardness $=2$ 500-3 000) on the resistance to DLC (hardness $=1300-1500 \mathrm{HV}$ ) films to abrasion was also analyzed.

The results show that: (i) the presence of a hard underlayer enhance greatly the DLC resistance to abrasion, (ii) TiAlCON film is more resistance to abrasion than DLC.

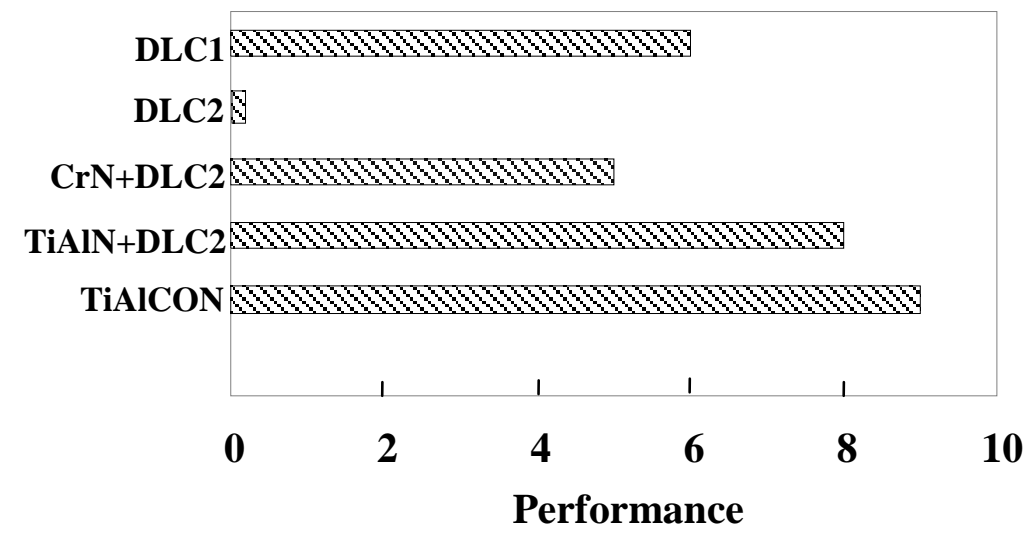

Figure 1. Performance of several black coatings after $48 \mathrm{~h}$ of wear by vibrations testing (40)

\section{References}

[1] D.R. Gabe, S.E. Gould, Surf. Coat. Technol. 35(1988)79691.

[2] Guofeng Cui, Ning Li, Jian Zheng, Qinglong Wu, Surf. Coat. Technol. 200 (2006) 6808.

[3] Vishal Saxena, R. Uma Rani, A. K. Sharma, Surf. Coat. Technol. 201 (2006) 855.

[4] S.N.Patel, O.T.Inal, Thin Solid Films. 113(1) (1984) 47.

[5] J.F. Monteiro, F. Oliveira, R. L. Reis, O. Paivan Palt. Surf. Finish. 79(1)(1992)46

[6] Guangyu Li, Liyuan Niu, Jianshe Lian, Zhonghao Jiang, Surf. Coat. Technol. 176 (2004) 215.

[7] G. R. Gabe, S.E. Gould, Surf. Coat. Technol. 35 (1988) 79.

[8] F. Jahan, B.E. Smith, Sol. Energy Mater. 20 (1990) 215.

[9] Guofeng Cui, Ning Li, Jian Zheng, Qinglong Wu, Surf. Coat. Technol. 200 (2006) 6808.

[10] Vishal Saxena, R. Uma Rani, A. K. Sharma, Surf. Coat. Technol. 201 (2006) 855.

[11] E. Wackelgard, Sol. Energy Mater. Sol. Cells, 56(1998) 35.

[12] M.L Cantu, A.M Sabio, A. Brustenga, P. G. Romero, So. Energy Mater. Sol. Cells. $87(2005) 685$.

[13] S.John, Met. Finnish. 95 (1997) 84.

[14] Vishal Saxena, R. Uma Rani, A. K. Sharma, Surf. Coat. Technol. 201 (2006) 855.

[15] N. S. Mehra, PhD thesis, Meerut University, India (1987)

[16] Cong, Song-Lin; Zhao, Rong-Gen; Zou, He-Shui; Guo, Jin-Qing; Ni, Xiang-Long IAF, International Astronautical Congress, 40th, Malaga, Spain, Oct. 7-13, 1989 http://adsabs.harvard.edu/abs/1989mala.iafcS....C (April - 7 - 2010) 
[17] N.C. MEHRA, S. K. Sharma, J. Mater. Sci. Lett. vol 8, nº 6 (1989) 707.

[18] J.K. Dennis, T.E. Such. Nickel and Chromium plating. Butterworth \& Co, Londres 1972

[19] Magdy A.M. Ibrahim, J. Appl. Electrochemistry, 36 (2006) 295.

[20] F.J. Monteiro, F. Oliviera, R. Reis, O. Paiva, Plat. Surf. Fin. (1992) 46

[21] M. Koltun, G. Gukhman, A. Gavrilina, Sol. Energy Mater. Sol. Cells 33 (1994) 41.

[22] R.E. Peterson, J.W.Ramsey, J. Vaccum Sci. Technol. 12 (1975) 174.

[23] J.H. Lin, R.E. Peterson, J. Vaccum Sci. Technol. 12 (1975)174.

[24] Ewa Wackelgard, Sol. Energy Mater. Sol. Cells 56 (1994) 35.

[25] M. Lira-Cantu, A. Morales Sabio, A. Brustenga, P. Gomez-Romero, Sol. Energy Mater. Sol. Cells. 87 (1-4) (2005)685.

[26] Guofeng Cui, Ning Li, Jian Zheng, Qinglong Wu, Surf. Coat. Technol. 200 (2006) 6808.

[27] www.cs.wpi.edu/ dfinkel/Sponsor/CM1.doc (April - 7- 2010)

[28] N. Karuppiah, S. John, S. Natarajan, V. Sivan, Bulletin of Electrochemistry 18 (7) (2002) 295.

[29] S. John and N. Karuppiah, Proc VIII Tamil Sciences Congress, M S University, Tirunelveli, (1998) 57.

[30] C.L. Aravinda, Parthasarathi Bera, V. Jayaram, A.K. Sharma, S.M. Mayanna, Materials Research Bulletin, 37 (2002) 397.

[31] C.L. Aravinda, S.M. Mayanna, P. Bera, V. Jayaram, A.K. Sharma, J. Materi. Sci. 21 (2002) 205

[32] S. Surviliene, L. Orlovskaja, S. Biallozor, Surf. Coat. Technol. 122 (1999) 235.

[33] M. Nikolova, O. Harizanov, P. Steftchev, I. Kristev, S. Rashkov, Surf. Coat. Technol. 34(1988)501.

[34] M. Aguilar, E.Barrera, M. Palomar-Pardavé, L. Huerta, S. Muhl, J. Non Cristal. Sol. 329 (2003) 31.

[35] A.K. Graham, Proc. Amer. Electroplaters Soc. 46 (61) (1959) 61.

[36] M.F. Quaely, Plating, 9 (1953) 982.

[37] C. Anandan, V.K. William Grips, K.S. Rajam, V. Jayaram, Parthasarathi Bera, Appl. Surf. Sci. 191 (2002) 254.

[38] Z. Abdel Hamid, Surf. Coat. Technol. 203(2009) 3442.

[39] M. R. Bayati, M. H. Shariat, K. Janghorban, Renewable Enery. 30 (2005) 2163

[40] R. Constantin, P.A. Steinmann, C. Manastereski, «Revêtements PVD decorative » in « Nanomatériaux, traitement et fonctionnalisation des surfaces », J. Takadoum (ed), p.141, Hermes, Lavoisier, Paris 2008.

[41] J.M. Chappé, F. Vaz, L. Cunha, C.Moura, M.C. Marco de Lucas, L. Imhoff, S.

Bourgeois, J. F. Pierson, Surf. Coat. Technol. 203 (2008) 804.

[42] S.J. Bull, Diamond Related Materials, 4(5-6) (1995) 827.

[43] A. Grill, Wear, vol. 168(1-2) (1993),143.

[44] T. Le Huu, H. Zaidi, D. Paulmier, P. Voumard, Thin Solid Films, (290-291) (1996) 126.

[45] Y. Liu, A. Erdemi, E.I. Meletis, Surf. Coat. Technol. 82 (1996) 48.

[46] J. Takadoum, J.Y. Rauch, J.M. Cattenot, N. Martin, Surf. Coat. Technol. (174-175) (2003) 427.

[47] A. Andritschky, M. Atfeh, K. Pischow, Surf. Coat. Technol. 203 (8) (2009) 952.

[48] Zu-Po. Yang ; CI. Lijiec ; James A. Bur ; Shawn-Yu. Lin ;Pulickel M. Ajayan ; Nano Letters, 8(2) (2008) 446.

[49] http://www.solardiy.info/?p=76 (April - 7 - 2010)

[50] http://www.theglobeandmail.com/news/technology/science/article660930.ece(April - 7 2010) 
[51] http://www.reuters.com/article/idUSN1555030620080116(April - 7 - 2010) 